\title{
THE PORTRAYAL OF TALIBAN IN THE EDITORIALS OF ENGLISH PRESS OF PAKISTAN: AN EVALUATION FROM 11 SEPTEMBER 2001 TO 30 SEPTEMBER 2007
}

\author{
Saima Kausar \\ Assistant Professor \\ Department of Communication and Media Studies, \\ University of Sargodha \\ Sargodha, Pakistan \\ saima.kausar@uos.edu.pk \\ Dr. Mudassar Hussain Shah \\ Assistant Professor \\ Department of Communication and Media Studies \\ University of Sargodha, \\ Sargodha, Pakistan \\ mudassar.hussain@uos.edu.pk \\ Maryam Waqas \\ Lecturer \\ Department of Mass Communication, \\ National University of Modern Languages, Lahore Campus, \\ Lahore, Pakistan \\ mwaqas@numl.edu.pk
}

\begin{abstract}
The invasion of United Sates and Allies in Afghanistan after 9/11, it becomes center of attraction for International media outlets. Taliban as former successors of Afghanistan and deadliest insurgents against the U.S. invasion and had influenced significantly socio-economic and security situation of Pakistan. Taliban widely debated in Pakistan among policy makers, security institutions, politicians, academia and media. This article analyzed the portrayal of Taliban in the English Press in the first seven years of U.S. invasion in Afghanistan. For this purpose, a qualitative study is conducted to analyze the editorials of three leading English language newspapers of Pakistan; The News, The Nation and Dawn from 11 September, 2001 to $30^{\text {th }}$ September, 2007. Accumulatively 1537 editorials are analyzed which reflect Taliban in the latent and




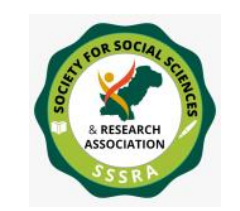

Pak. Journal of Int'L Affairs, Vol 4, Issue 3 (2021)

The Portrayal of Taliban in the Editorials ...

manifested context in editorials. The coding sheet framed Taliban in the content and context as positive, negative and neutral. The finding of study revealed that all three leading English newspapers of Pakistan; The News, The Nation and Dawn significantly projected Taliban negative and neutral whereas they got meager positive portrayal. However, studies (Nadeem, 2017; Rasul et. al., 2016) assert that it is in line with State policy, which reflect them as terrorist and threat to the internal security of Pakistan.

Key Words: Taliban, editorials, The News, The Nation, Dawn, Pakistan

\section{Introduction}

The disaster that occurred on September 11, 2001, brought devastating outcomes for all Muslims around the world. The entire impression and perception of Islam and Muslims changed completely, and they were characterized as fear-based oppressors, fundamentalists, radicals, and terrorists. The world began seeing them as a continuous danger for all the people around the globe. All this occurred on September 11, 2001 in which the world trade Centre was attacked through hijacked planes, which resulted in the death of about 2763 individuals (Crenshaw \& LaFree, 2017, p.41). The administration of the United States utters that this whole incident was a plan by an extremist group of Islam known as Al-Qaeda. It was thought that Al-Qaeda groups were living in Afghanistan and were living with the cooperation of the Taliban. They all were targeted after that incident. Then the U.S. in response to this incident started wars on terror. That was the moment that troublesome for Pakistan when President Bush gave a final ultimatum to Pakistan by saying, "you are either with us or with them" (Jabeen, 2009). So in this manner, Pakistan additionally became one of the central members in this "battle against terror".

The incident of September 11 resulted in a devastating impact on all the Muslims around the world. As Muslims were under constant pressure to be extremists, they were perceived as a threat to the world. Nevertheless, Muslims had to confront continuous discrimination by all the Western countries. Furthermore, President Bush gave a final statement to the world that "you are either with us or with the terrorists" (Woodward, 2002).

The United States expressed reason for the attack on Afghanistan was to arrest Osama bin Laden. In addition, they wanted to abolish Al-Qaeda totally and eliminate the Taliban and the system, which had offered great support and security to Al-Qaeda. After the attack on Afghanistan by the US led Western block of NATO, the Waziristan clash began in 20042006. It was a time when tensions surrounded by the Army of Pakistan as they started 


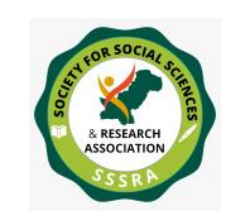

Pak. Journal of Int'L Affairs, Vol 4, Issue 3 (2021)

The Portrayal of Taliban in the Editorials ...

searching Al-Qaeda group in the Waziristan area (FATA); it escalated into armed confrontation by nearby tribesmen. The battle was viewed as a part of the War on Terrorism and had associations with the Taliban insurrection in Afghanistan (Atran, 2010). It seems that entire world has drawn its attention towards the Muslims and Taliban; they were being accused of every act of terrorism. So, during 2001-2007 significant coverage has been given to these issues, and Muslims, Taliban, and terrorism have been the main focus of national and international media. Many researchers (Phillips and Kamen, 2014; Johnson and Mason, 2007; Rubin, 2002) have already been conducted their studies on the coverage of Taliban.

This investigation tries to see how Pakistani print media have been covering the Taliban and what sort of coverage was given to them. For this reason, the editorials of The Nation, The News, and Dawn have been analyzed. By considering that these editorials represent the policy of the newspaper, it has been chosen for performing content analysis. In Pakistan, the press is known to be more trustworthy as compared to electronic media. English is a global language, and in Pakistan, essentially, individuals who are highly qualified and policymakers prefer to read English newspapers. That is the reason it is additionally called elite class newspapers. It is observed that relatively English press is responsible. The Nation, Dawn, The News are three significant newspapers of Pakistan and have huge circulation and admiration among the readers. Overall, these papers stay genuine and mindful of the issues of the country and worldwide. Also, the official site of the government of Pakistan grades The Nation, Dawn, and The News as the top three newspapers of Pakistan. This study intends to analyze the portrayal of Taliban in Editorials of the English press of Pakistan from September 11, 2001 to 2007.

\section{The Taliban: Origin and Insurgency in Afghanistan}

Taliban are associated with the Sunni sect, and the movement of Pashtun nationalists governed a large part of Afghanistan from 1996 to 2001, when their chiefs were taken out from power by a combination of military action of Northern Alliance and NATO states. Devoted radical insurgents mostly depicted as "Taliban" in the media. Some faction of Taliban lived in the Frontier Tribal Areas of Pakistan, and they were engaged with an extended revolutionary battle against the US led administration of Afghanistan. The allied NATO powers contributed to the activities to expand their operations and to grow their tasks and impact in Pakistan. The movement of Taliban was originally ruled by Mullah Mohammed Omar. Under Mullah Omar, there was "a combination of previous little unit military administrators and Madrasah instructors," and afterward majority considerably a large portion of them had taught in Islamic religious schools in Pakistan. A massive majority of Taliban belonged to ethnic Pashtuns that were from Southern 


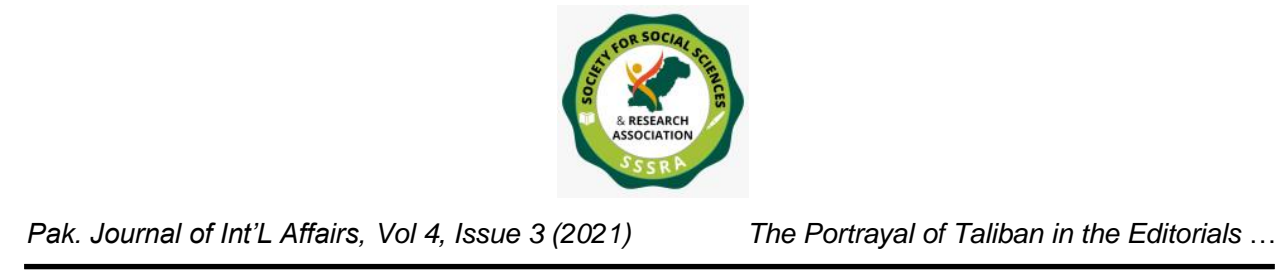

Afghanistan, and some were from alongside border of Western Pakistan. The small numbers of volunteers were from Islamic countries or areas of North Africa, the Central East, and the previous Soviet Union (Marsden, 1998). However, Kabul and much more area of Afghanistan was in control of Taliban for five years, they got political acknowledgment only from three countries including Pakistan, Saudi Arabia, and the UAE (Ibrahimi, 2017).

In spite of the fact that there is no proof that the CIA defended and directly supported the Taliban or Al Qaeda but some evidence were got that the United States' military is supporting to Taliban in the start of the 1980s. The CIA and the ISI gave weapons to Afghans who were opposing to the Soviet interruption in Afghanistan, and the ISI helped them to gather all the fundamentalists from the entire Muslims world to go for battle against the Soviets (Riedel, 2010). The Taliban who were situated in the Kandahar, Uruzgan and Helmand areas were predominantly ethnic Pashtuns and were mostly Durrani Pashtuns(Campana \& Ducol, 2011). The first significant majority of military actions of the Taliban was held in October-November 1994 when they moved from Maiwand in Southern Afghanistan to seize Kandahar and its nearby regions in this action they lost two or three dozen men. In September 1996, they had taken over Afghanistan's capital Kabul.

The association of Taliban with ethnicity was blended. Deobandi and anti-nationalist had this faith that they had opposite ethnic and feudal patterns, and they thought to be removed from the positions of authority. Nevertheless, they were extremely hesitant to share power and their positions with predominant Pashtuns, where Pashtuns made up just (42\%) of the populace (Borthakur and Kotokey, 2020).

All the senior Tajik, Uzbek, and Hazara officials at the national level were substituted by Pashtuns whether they were eligible for that positions or not. The ministry departments were stopped functioning because of their lack of knowledge and skill in the relevant field. Taliban's were more dominated in the local units of government such as counsels of Kabul or Herat as a comparison to the locals. This was the situation even when the Taliban who were Pashto speaking were unable to interconnect by Persian speaking Afghans (generally 50\% of the number of inhabitants in Afghanistan spoke Dari or other non-Pashtun languages) (Ibrahimi, 2017). The Criticizers protested that the absence of native presentation in management had turned the Taliban into an occupying power (Rashid, 2010). The Taliban proclaimed that the ethnic cluster of Hazara, which is nearly (10\%) of Afghanistan's populace, is not Muslims. Crews and Tarzi (2009) stated that the philosophy of the Taliban was not static. Prior to the Kabul's capture, individuals from the Taliban discussed moving to one side once an administration of "good Muslims" took 


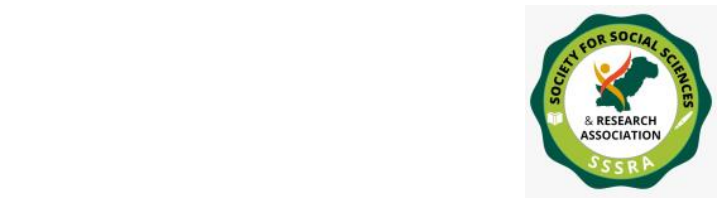

The Portrayal of Taliban in the Editorials ..

force and the rule of law will be reestablished. The procedure of decision-making in the Taliban of Kandahar was based on Pashtun ancestral gathering called Jirga, which was also believed to be an initial Islamic modal. Conversations were trailed by agreement of the adherents.

The Taliban go through criticism for their severity toward the people who resisted the (Bid'ah) rule. A few Muslims criticized that numerous Taliban, for example, prohibitions on applauding during games, flying kites, cutting beard or sports for ladies - had no legitimacy in the Quran or Sharia. In the month of February 1998, strict religious police enforced all ladies of the Kabul and gave new guidelines and ordered all the people living in the houses to darken their windows, so ladies would not be noticeable from the outdoor.

They allowed for girls home schools for counting their studies. In June 1998, the Taliban prevented all ladies from going to general emergency clinics. Laub (2014) states in the report of the Council of Foreign relations that strict actions and policies of Taliban for their native troops resulted in revolt wherein a huge number of the Taliban's best soldiers were killed. In 1997, Ahmad Shah Massoud conceived an arrangement to use strategies in the southern fields to overcome the Taliban who have entered the Hazara and Uzbek city of Mizar-e-Sharif. On August 8, 1998, the Taliban took over again Mazar-e-Sharif and this time retaliated their prior conquest and made more global debates. They held control over the vast majority of the country until the incident of 2001 9/11 assaults.

In the whole regime of Taliban or "Islamic Emirate of Afghanistan," they acquired political acknowledgment from Pakistan, UAE, and Saudi Arabia, every one of whom additionally gave help to them. On the other hand, many countries of the world like Russia, Iran, India, Uzbekistan, Kyrgyzstan, and Tajikistan, and later also the USA, gone against the Taliban and supported their opponents Northern Associations. Taliban had a profound impact on Pakistan. Toward the beginning of August of 1998, the Taliban's hardships of dealing with the foreign masses more worsen. Subsequent to the attack of Mazar-i-Sharif (Bergen \& Tiedemann, 2012).

An important issue during the Taliban's rule was its relations with the Assembled Countries (U.N.) and non-administrative associations (NGOs). Twenty years of nonstop fighting, first with the Soviets and afterward between Mujahideen, had crushed Afghanistan's framework and economy. There was no running water, lack of electricity, a small number of phones, or ordinary energy supplies. Fundamental necessities like water, food, and lodging, and others have wildly had a shortage. Likewise, the group and family structure that gives Afghans social and financial security was additionally severely 


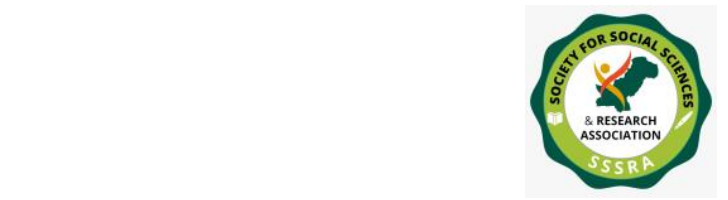

The Portrayal of Taliban in the Editorials ..

harmed. Afghanistan's newborn child mortality was the highest on the planet. A quarter of all kids become dead before they reach five years. This death rate was much higher than most of the other developing nations.

Murthy (2002) stated that afterward, global charitable and developmental associations (NGOs) played a big role in the supply of foodstuff in Afghanistan and opportunities for employment and construction work, etc. However, despite all these things, the behavior of the Taliban towards U.N. and NGO aid was quite mistrusting. They do not pose to be grateful to them. Osama bin Laden in 1996 went to Afghanistan from Sudan, Taliban-alQaeda associations were reinforced when the marriage of the son of bin Laden was done with the daughter of Omar's. After 1998 U.S. international designation did attack in Africa bin laden, and many al Qaeda group entities were accused in U.S. criminal court. Taliban's saved bin Laden's extradition by the claim that he had disappeared in Afghanistan or Washington, and they do not have any proof or any verification that bin laden is engaged in terrorism-based activities. After the PENTTBOM investigation 2004 and the incident of September 11 United States of America gave an ultimatum to the Taliban.

These are as follows:

- Send all the heads of al Qaeda to the United States.

- Freed all incarcerated foreign citizens.

- Instantly close each and every militant instructional camp.

- Handover each terrorist and their followers to proper consultants

- Offer full access of U.S. to the terrorist instructional camps for full inspection

On thirteenth November Taliban withdrew from Kabul and Jalalabad. They also gave up their last city Kandahar, and they got scattered in different locations. The insurgence continued in the form of guerrilla wars. They sustained help from the tribes and different radical clusters of border areas of Pakistan and the minor number of NATO powers joined with the long history of opposition and segregation and encouraged the perception that Taliban heads and pioneers were surviving and will uphold the impact over Afghanistan in the future.

\section{Methodology}

This study is plan to find that how Taliban were portrayed in the English Press of Pakistan in the first phase of their resistance against the U.S. invasion in Afghanistan on 11 September 2001 to 2007 . For this purpose, a qualitative study is designed to find the coverage given to Taliban in the editorials of top three English newspapers which are 


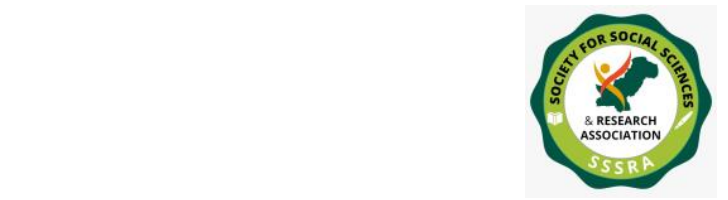

Pak. Journal of Int'L Affairs, Vol 4, Issue 3 (2021)

The Portrayal of Taliban in the Editorials ..

highly circulated in Pakistan that are 'The News', 'The Nation' and 'Dawn'. Accumulatively, 1537 editorials are analyzed that were published in the first seven years of U.S Invasion in Afghanistan. All significant editorials which indicated Taliban, Afghan insurgency, terrorists in Afghanistan, Islamic Emirates of Afghanistan, extremism, bomb blast, Militants, attack on Americans, killing and ransom for Jihad and other relevant key words which appeared in the editorials are potentially part of this this study. The direction of content defined in the coding sheet of this study on the frames of positive, negative and neutral. The frames list the ideologies, phrases, catchy words, the intensity of the words or slogan direct researchers to understand manifest and latent meaning of the content and put in the said frames. The data is presented and explained in the graphical form.

\section{Findings and Discussion}

Results of this study reflect that accumulatively (1537) editorials were published in Pakistani English press on the issue of Taliban and their activities in the first seven years of U.S invasion in Afghanistan. After the 11 September 2001 attacks in United States (84) editorials were published in which (34) in The News, (26) in The Nation and (24) in the Dawn whereas in year 2002, The News and Dawn each published (50) editorials while The nation published (54) editorial. In the year 2003, the wave of terrorism erupted in Pakistan and Taliban's sympathizers started attacks in the Tribal areas of Pakistan. (287) editorials published by all three newspapers in which (94) published by The News, (110) by The Nation and (83) editorials by Dawn. Pakistan Army started military operation against the foreign militants and their supporters in the South Waziristan and Taliban portrayal slightly declined in the year 2004. (243) editorials published in the English newspapers in which (82) published in the News, (87) in The Nation and (74) in Dawn. However in 2005, although it was devastating earth quake in Pakistan administered Kashmir, NWFP and part of Afghanistan and thousands of people died in it but it was slightly rise in the portrayal of Taliban where (292) editorials published in which The News published (100) editorials, The Nation (109) and Dawn (83). In 2006, the military operations by Pakistan Army in South Waziristan, Part of NWFP and drone attacks in tribal regions fanned the terrorism in Pakistan but the Taliban portrayal slightly reduced and accumulatively (219) editorials appeared in all three newspapers where (79) editorial reported in The News, (78) in The News and (62) appeared in the Dawn. However, in 2007 accumulative (256) editorial published on the issue of Taliban in which (93) published in The News, (87) in The Nation and (76) in Dawn. See Figure 1. 


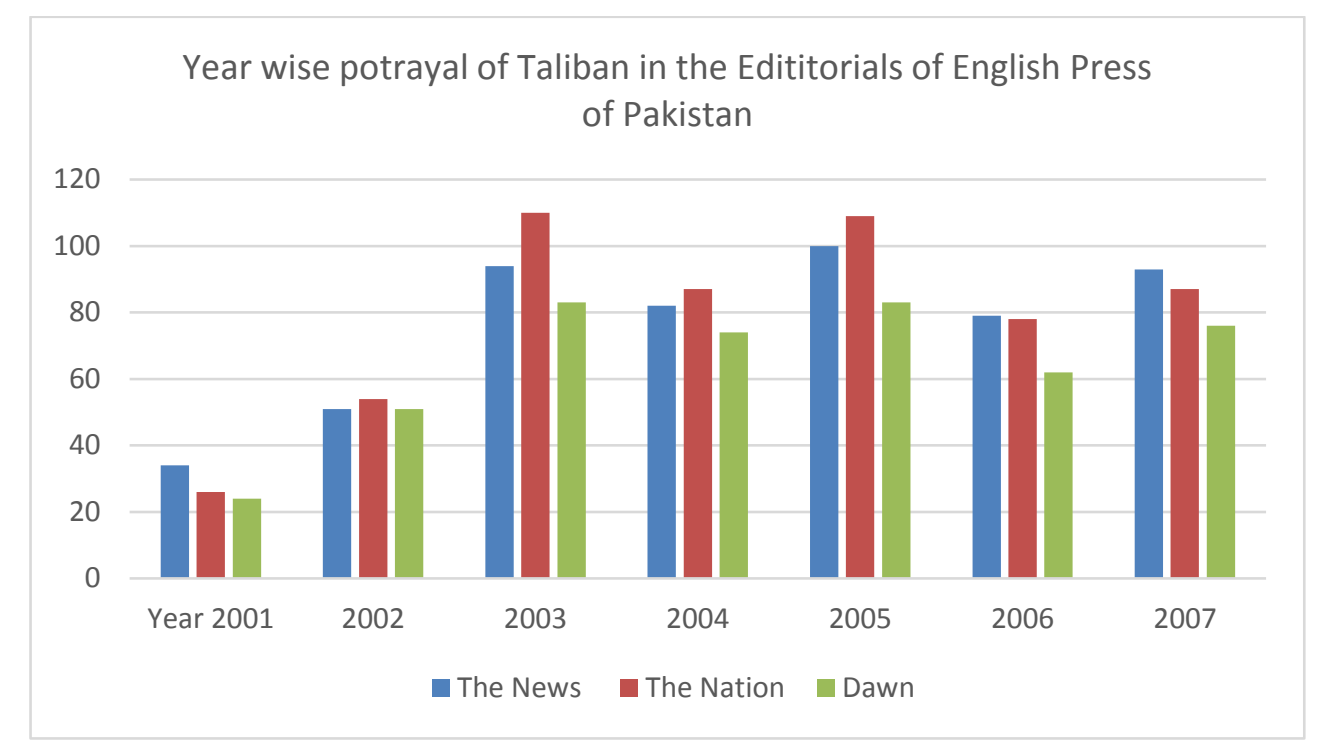

Figure 1 Year wise portrayal of Taliban in the Editorials of English Press of Pakistan

The figure 2 shows that there is the variation in the coverage of Taliban in the entire period from 11 Sep. 2001 to 2007. The News portrayed Taliban in year 2001 (26.47\%), The Nation (26.92\%) and The Dawn (29.17\%), in year 2002 The News coverage is slightly high than previous year which portrayed $(29.41 \%)$, The Nation $(25.92 \%)$ and Dawn given coverage (33.33\%).

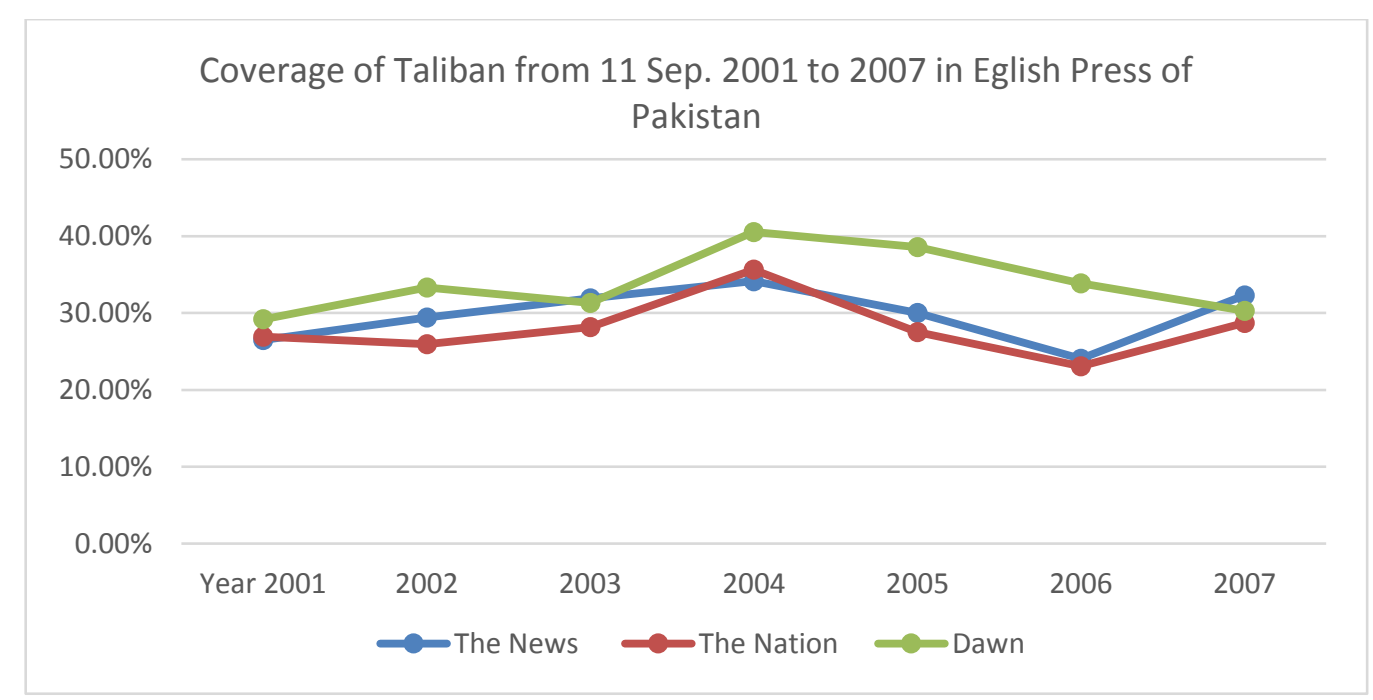

Fig. 2 Coverage of Taliban in Editorials of English Press of Pakistan 


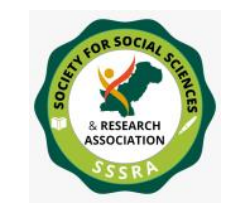

The Portrayal of Taliban in the Editorials ..

However, this coverage in year 2003 increased slightly in which The News $(31.91 \%)$, The Nation (28.18\%) and Dawn (31.32\%) reported in their editorials. In the year 2004, significant coverage observed in which $(34.15 \%)$ by The News, $(35.63 \%)$ The Nation and (40.54\%) Dawn. However, this slightly decreased in 2005; The News portrayed Taliban (30\%), The Nation (27.52\%) and Dawn (38.55\%). This portrayal continued in year 2006, The News (24.05\%), The Nation (23.08\%) and Dawn (33.87\%). In addition, the editorials of all three newspapers respectively portrayed The News (32.26\%), The Nation (28.73\%) and Dawn (30.26\%). See Figure 2.

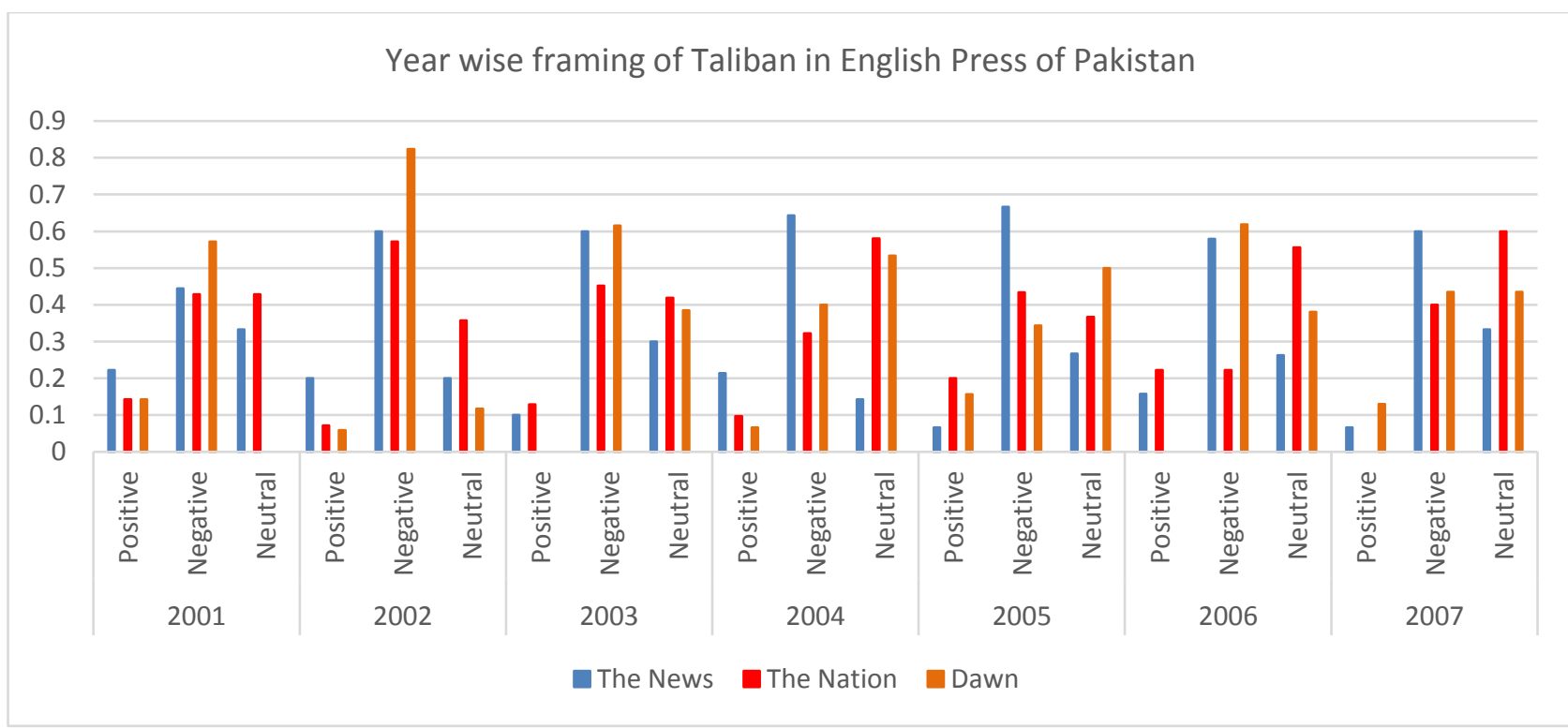

Figure 3 Year wise framing of Taliban in the English Press of Pakistan

The framing of Taliban in the editorials of The News, The Nation and Dawn during the year 2001 to year 2007 depicts in the Figure 3. The portrayal of Taliban analyzed on the frames of positive, negative and neutral frames. The overall significant negative portrayal of Taliban reflects during the entire period and it significantly framed neutral in this period. However, meager positive portrayal revealed in the first phase of United States invasion in Afghanistan. The significant negative portrayal observed in the year 2002, 2003, 2004, 2005, 2006 and 2007. Whereas, year 2001, 2003, 2004, 2005, 2006 and 2007 are marked neutral portrayal in the editorials of said newspapers of Pakistan. However, Dawn had not framed neutral in year 2001 and slightly neutral (11.7\%) in year 2002 and in the later years neutral frames varied based on the issues dealt by the government of Pakistan and Taliban's comrades activities in Pakistan by the Dawn. In the first year of Invasion in Afghanistan in year 2001, the accumulative positive coverage 


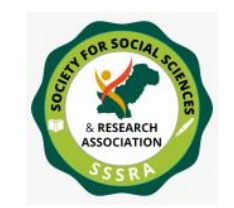

The Portrayal of Taliban in the Editorials ...

given by these newspapers were $(16.9 \%)$, (48.14\%) negative and $(37.5 \%)$ by two newspaper The News and The Nation whereas Dawn had not reported positive in this year. In year 2002, the positive coverage of Taliban was (10.6\%), negative coverage $(66.49 \%)$ and neutral coverage $(22.49 \%)$. In year 2003, accumulative positive coverage of Taliban appeared $(11.45 \%)$ and Dawn newspaper not given any positive coverage to Taliban in their editorials whereas accumulatively (55.56\%) negative and (36.79\%) neutral. In the year 2004, accumulative positive coverage by all three newspapers was $(12.34 \%)$, negative $(45.51 \%)$ and neutral $(42.07 \%)$. In year 2005 , accumulative positive coverage by all three newspapers was $(14.1 \%)$, negative $(48.1 \%)$ and neutral $(37.78 \%)$. In the year 2006, accumulative positive coverage by the The News and Nation to Taliban in the editorials was (19\%) whereas Dawn had not given positive coverage in this year. Whereas, negative portrayal of Taliban (47.33\%) and (39.98\%) neutral. In the year 2007, The News and Dawn accumulative coverage was (9.85\%) and The Nation did not positive image of Taliban. However, Taliban negatively portrayed (47.82\%) and neutral $(45.60 \%)$. The results reveal over very significant negative image of Taliban in the English press of Pakistan whereas neutral portrayal of Taliban is also significant. However, they were not very significant positively portrayed.

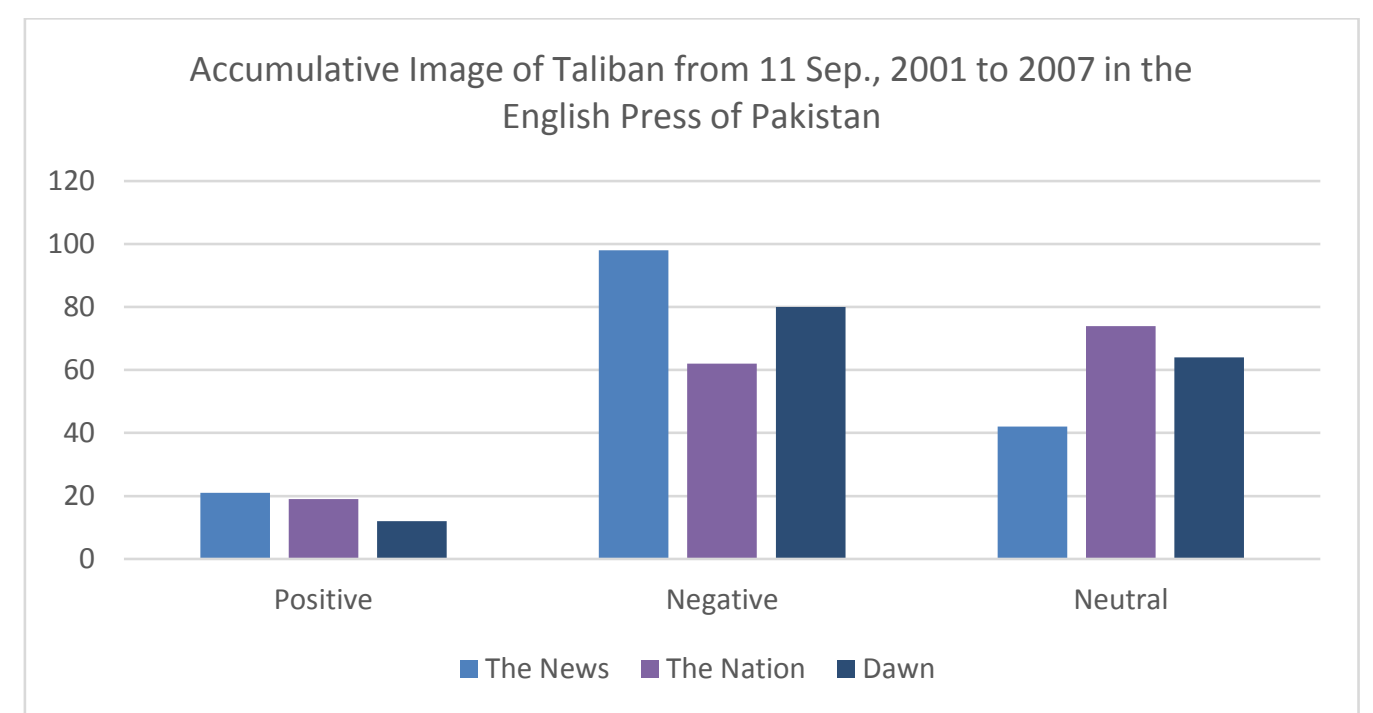

Figure 4. Accumulative Image of Taliban in the Editorials of English Press of Pakistan

Figure 4 reflects accumulative image of Taliban in the editorials of English Press of Pakistan from Sep. 11, 2001 to Sep. 2007. The accumulative framing of Taliban reflected in the editorials of three leading English newspapers i.e. The News, The Nation and Dawn and framed in the positive, negative and neutral categories. The News overall 


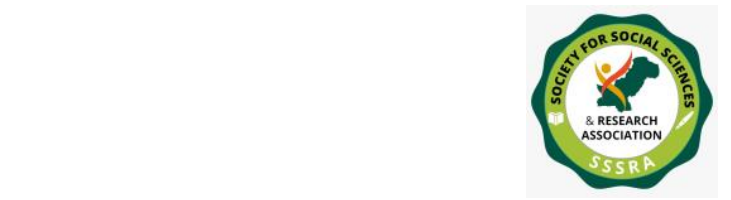

The Portrayal of Taliban in the Editorials ..

framed $(21 \%)$ positive in the entire period, The Nation (19\%) and Dawn (12\%). However, the framing of Taliban negative reflected significant in the seven years period among all three newspapers. The News gave (98\%) negative framing, The Nation (62\%) and Dawn $(80 \%)$ negative. Significant proportion of neutral framing reflected in the entire period, The News gave (42\%) neutral framing to Taliban, The Nation (74\%) and Dawn (64\%). Hence, all three newspapers have significant influence on the literate class, policy makers and business elite of the country, which significantly reflect that they might take editorial influence published in the entire time.

Results reveal that during the entire period, Afghan Taliban significantly discussed in the editorials of Pakistani English press. The acquisitively, 1537 editorials published in the English press of Pakistan which debated Taliban in the entire time. However, the discourse in the editorial varied in coverage by the The News, The Nation and Dawn. Rasul et al. (2016) argued that elite English press of South Asia (India and Pakistan) reflects the foreign policy elements of their governments on the Afghan Taliban or conflict in Afghanistan. However, slightest coverage in editorials are given by The Nation in year 2006 which was (23.08\%) and very significant by Dawn in year 2004 (40.54\%). Rasul et al. (2016) assert that Dawn report Taliban in their editorials engrossed and composed. Significant focus remained on the issues how government of Pakistan took initiatives to reduce the threat of terrorism from Taliban and their associates. Nadeem et al. (2019) evaluate in the editorial framing of Taliban in The Nation and Dawn and find that The Nation is pleasanter to Taliban than the Dawn. Conversely, Dawn advocated sterner stance in their editorial as compare to The Nation. However, both newspaper reflect the state policy in which Taliban are declared as terrorist and considered security threat to the internal security of Pakistan (Nadeem, 2017).

In evaluation of seven-year editorial treatment by the all three newspapers, significant negative treatment has given to Taliban by all three newspapers. Whereas, Taliban have least positively portrayed in said time. However, they were significantly neutrally appeared in the editorials. Malik \& Iqbal (2010) affirm in the discourse analysis of editorials of Dawn and The News that Taliban image is constructed negative in the editorial of English press where they presented derogatory and stereotypical in the framing of English press. Rasul et al. (2016) noted that in the latent meaning and manifest Taliban and Afghan war is portrayed negatively in the English newspapers of Pakistan. They also assert that editorials stressed the regional corporation to curb the menace of terrorism in the region. The overall, Taliban have been significantly projected negative and neutral image in the editorials of English Press of Pakistan and there is slighter positive depiction in the editorials revealed in the entire study period. Bolt (2012) argues that violent image of the extremist, separatist and modern insurgent movements 


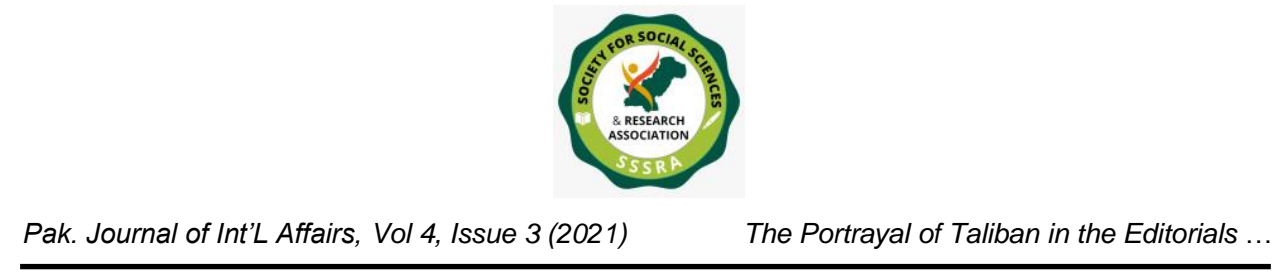

are so powerful, through which they communicate, disseminate and cultivate their ideologies through the modern means of communication. However, their act is highlighted as the fundamental grievances to the power structure of global governance. Bolt assert that in the war of ideas the negative image projected as strategic instrument of tool of war.

\section{Conclusion}

The situation of Afghanistan always influenced Pakistan in terms of security, social, cultural, political and economic. Taliban takeover Afghanistan from war lords in 1998 and maintained their insurgency in Afghanistan against the U.S and NATO forces after 9/11. Pakistan significantly influenced from the war turned Afghanistan and Taliban and faced war against terrorism in the entire time. This study indicate that very significant proposition of editorials described varied aspect related to Taliban, their actions, the militant activities of their sympathizers in Pakistan, terror against civilians, suicide attacks on forces and civilian population and how to tackle this menace. However, The Nation given least coverage to Taliban in comparison to the other English language newspapers because The Nation as a media group aligned themselves pro far right thought which leaned to Islamic ideals. Whereas, The News has given moderate coverage as compare to Dawn. The News belongs to Jang group of Pakistan, which reflect themselves as moderate and commercial media group. However, significant coverage is given to Taliban by Dawn. It is the newspaper, which reflects the government policy on the foreign policy issues. While, framing of Taliban by all three newspapers, they reflect significantly negative and neutral in the editorials whereas slightest positive depiction revealed in the first seven years of U.S and NATO invasion in Afghanistan. Overall, in the study period, Taliban very significantly portrayed negative, significantly neutral and they have least portrayed positive image in the editorials of 9/11 to 2007. Studies suggest that the all three newspapers reflect state policy in which Taliban and their sympathizers considered as an extremist group pose threat to the internal security of Pakistan. 
The Portrayal of Taliban in the Editorials ..

\section{References}

Aman, D. S., \& Jan, D. M. A. (2020). A Historical Analysis of Trends in Pakhtun EthnoNationalism. South Asian Studies, 30(2), 70-85.

Andrabi, T., Das, J., Khwaja, A. I., \& Zajonc, T. (2012). Madrasa Metrics: The Statistics and Rhetoric of Religious Enrolment in Pakistan. In Beyond Crisis (pp. 452-473). Routledge Inc.

Atran, S. (2010). A question of honour: Why the Taliban fight and what to do about it. Asian Journal of Social Science, 38(3), 343-363.

Bergen, P., \& Tiedemann, K. (2012). Talibanistan: negotiating the borders between terror, politics, and religion(Eds.) Oxford University Press.

Bolt, N. (2012). The violent image. Insurgent Propaganda and the New Revolutionaries. Hurst \& Company.

Borthakur, A., \& Kotokey, A. (2020). Ethnicity or religion? The genesis of the Taliban movement in Afghanistan. Asian Affairs, 51(4), 817-837.

Campana, A., \& Ducol, B. (2011). Rethinking terrorist safe havens: Beyond a state-centric approach. Civil Wars, 13(4), 396-413.

Crenshaw, M., \& LaFree, G. (2017). Countering terrorism. Brookings Institution Press.

Crews, R. D., \& Tarzi, A. (2009). The Taliban and the crisis of Afghanistan (Eds.).. Harvard University Press.

Hussain, Z. (2010). The scorpion's tail: The relentless rise of islamic militants in Pakistanand how it threatens America. Simon and Schuster.

Ibrahimi, S. Y. (2017). The Taliban's Islamic Emirate of Afghanistan (1996-2001): 'WarMaking and State-Making'as an Insurgency Strategy. Small Wars \& Insurgencies, 28(6), 947-972.

Jabeen, M. (2009). Either you are with us or against us. South Asian Studies, 24(2), 175191. 
The Portrayal of Taliban in the Editorials ...

Johnson, T. H., \& Mason, M. C. (2007). Understanding the Taliban and insurgency in Afghanistan. Orbis, 51(1), 71-89.

Karlsson, P., \& Mansory, A. (2008). Islamic and modern education in Afghanistan: Conflictual or complementary. Institute of International Education, Stockholm University.

Kleiner, J. (2000). The Taliban and Islam. Diplomacy and Statecraft, 11(1), 19-32.

Laub, Z. (2014). The Taliban in Afghanistan. Council on Foreign Relations, 4(7), 1-9. Malik, S., \& Iqbal, Z. (2010). Construction of Taliban image in Pakistan: Discourse analysis of editorials of Dawn and The News. China Media Research Journal, 7(2), 46-56.

Marsden, P. (1998). The Taliban: War, religion and the new order in Afghanistan. Palgrave Macmillan.

Murthy, C. S. R. (2002). Taliban and the Afghanistan Problem, 1996-2001: Role of the U.N. Himalayan and Central Asian Studies, 6(1), 4-34.

Nadeem, M. U. (2017). Pakistani print media and Taliban: A test of media conformity theory. VFAST Transactions on Education and Social Sciences, 5(1), 55-60.

Nadeem, M. U., Bokhari, I. H., Khan, M. A., \& Mustafa, F. (2019). An Examination of Media Frames Regarding Taliban: A Comparative Study of the Editorials of Dawn and The Nation. Pakistan Journal of Social and Clinical Psychology, 17(1), 68-72.

PENTTBOM investigation (2004) The September 11 detainees: A review of the treatment of aliens held on immigration charges in connection with the investigation of the September 11 attacks, United States, Department of Justice. Office of the Inspector General (Report).

Phillips, M., \& Kamen, E. (2014). Entering the black hole: The Taliban, terrorism, and organised crime. Contemporary Voices: St Andrews Journal of International Relations, 5(3), 60-75.

Rashid, A. (2010). Taliban: militant Islam, oil and fundamentalism in Central Asia. Yale University Press.

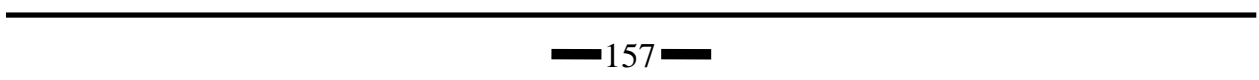


Rasul, A., Robinson, B. C., \& McDowell, S. D. (2016). The Taliban factor: conflict in Afghanistan and elite South Asian newspapers. The Journal of International Communication, 22(2), 273-292.

Riedel, B. (2010). The Search for al Qaeda: Its Leadership, Ideology, and Future. Brookings Institution Press.

Rokadia, F. D. (2009). Madressas as terror schools: The myth and the reality. American University. Press.

Rubin, M. (2002). Who is responsible for the Taliban. Middle East review of international affairs, 6(1), 1-16.

Woodward, B. (2002). Bush at war. Simon and Schuster Publishers.. 